\title{
Linalool, citral, eugenol and thymol: control of planktonic and sessile cells of Shigella flexneri
}

\author{
Moisés Tomás Ngome ${ }^{1}$, José Guilherme Lembi Ferreira Alves ${ }^{1 *} \mathbb{D}$, Ana Cristina Freitas de Oliveira', \\ Patrícia da Silva Machado², Olga Lucía Mondragón-Bernal ${ }^{1}$ and Roberta Hilsdorf Piccoli ${ }^{3}$
}

\begin{abstract}
The antimicrobial activity of linalool, citral, eugenol and thymol was determined in growth studies of both planktonic (PC) and biofilm cells (BC) Shigella flexneri. These components were evaluated either in isolation or in combinations using a sequential experimental strategy with Plackett \& Burman and central composite rotational designs totaling 47 treatments. The minimum inhibitory concentration for $P C$ was $0.125 \%\left(v v^{-1}\right)$ for linalool and $0.5 \%\left(v v^{-1}\right)$ for citral, eugenol and thymol. The biofilm minimum bactericidal concentration was 3 and $1 \%\left(v v^{-1}\right)$ for linalool and citral, respectively, and $2 \%\left(\mathrm{v}^{-1}\right)$ for eugenol and thymol. In the mixtures, the minimum concentrations in the efficient assays for PC growth inhibition were $0.0003,0.0443$ and $0.0443 \%\left(v v^{-1}\right)$, for linalool, citral and thymol, respectively. In the BC, only two assays with concentrations of $0.0558,0.0558$ and $0.319 \%\left(v^{-1}\right)$ and $0.035,0.035$ and $0.3999 \%$ $\left(v v^{-1}\right)$ for linalool, citral and thymol, respectively, inhibited Shigella growth. Synergism was observed among the components, where PC and BC growth inhibition occurred at lower concentrations than those noted individually. The bactericidal effect of the components in microplate was different from the observed in stain steel coupons. Therefore, the obtained model can describe and predict the PC count of S. flexneri in medium with the tested compounds and they could be an alternative for the use in microbiological control in food industry.
\end{abstract}

Keywords: Antimicrobial activity, Essential oils, Synergism, Pathogenic bacteria

\section{Introduction}

Shigella spp. are rod-shaped Gram-negative bacteria belonging to the family Enterobacteriaceae (Kane and Dorman 2012). The genus Shigella comprises four subgroups traditionally known as species: Shigella boydii, S. sonnei, S. dysenteriae and S. flexneri (Cruz et al. 2014; Nüesch-inderbinen et al. 2016; Grimont et al. 2007). Among the enteric pathogenic bacteria transmitted by food, Shigella is one of the most common (Hu and Wai 2017). They are pathogens responsible for severe diarrheal diseases in young children worldwide, especially in developing countries (Kane and Dorman 2012; Mani et al. 2016). Shigella spp. can invade the mucosa of the

\footnotetext{
*Correspondence: jlembi@dca.ufla.br

${ }^{1}$ Laboratory of Bioprocess Engineering, Department of Food Science, Federal University of Lavras, B.O.: 3037, Lavras, MG, 37.200.000, Brazil Full list of author information is available at the end of the article
}

large intestine in humans, causing inflammation and damage to the epithelium, thus giving rise to the disease called shigellosis (Arena et al. 2015). The number of deaths caused by this disease was estimated at 40,000 in 2010 , whereas in 2013,34,400 deaths of children under the age of five worldwide were estimated due to Shigella infections (Mani et al. 2016). In the United States, approximately 500,000 cases of shigellosis are annually reported (CDC 2013).

Foodborne illness have always been a threat to human health. They bring the emerging concern of public health in all continents, with numerous cases associated with the presence of biofilms (Srey et al. 2013).

Biofilms are associations of microorganisms attached to a surface and involved in extracellular matrix of polymeric substances (Simões et al. 2010). Any type of microorganism can form biofilm in inhospitable environments in order to survive and play an important role in several 
infections. The formation of biofilms is a systematic and dynamic process divided into five stages: (i) initial attachment, (ii) irreversible attachment, (iii) initial development of the biofilm architecture, (iv) maturation and (v) dispersion. The initial attachment stage is very important once it is reversible (Srey et al. 2013). In this stage, cells are called planktonic, i.e., non-adherent cells different from biofilms that have sessile cells (Costa et al. 2017).

In the food industry biofilms are generally found inside closed surfaces, such as pipes where liquid flows on solid surfaces. On open surfaces, fouling allows microbial retention (Whitehead and Verran 2015). Moreover, it is well reported that biofilm has become a problem in the food industry because it makes its population resistant to antimicrobial agents and to cleaning (Srey et al. 2013) due to their particular intrinsic characteristics, thus resulting in an increasingly negative impact on the food sector (Srey et al. 2013). In literature few studies with $S$. flexneri biofilm were done.

There is a trend of reducing the use of chemical sanitizers with antimicrobial activity in the food industry due to their negative effects (Souza et al. 2014; Moradi and Sadeghi 2017). Moreover, much pressure has been imposed by consumers and legal authorities linked to the food sector mainly focused on adopting more natural alternatives in the food production chain (Beyki et al. 2014; Souza et al. 2014). In this sense, the use of essential oils and their components, which are natural products, arises as an alternative for the control of many foodborne pathogens and degrading microorganisms (Bassolé and Juliani 2012). The essential oils and their components, such as linalool, citral, eugenol and thymol (Goldbeck et al. 2014; Ait-Ouazzou et al. 2011; Chauhan and Kang 2014), e.g., have already shown to play an important role in the discovery of new antibacterial agents (Araújo et al. 2017; Hyldgaard et al. 2012; Mahdavi et al. 2017). Although the mechanism of the antimicrobial activity of oils has not been fully understood, it is known that these make the membrane of bacterial cells more permeable, causing leakage of cytoplasmic components and then cell inactivation (Chai et al. 2016).

Therefore, the aim of the present study was to evaluate the growth inhibition of planktonic cell and biofilm of Shigella flexneri INCQS 00152 through both isolated and combined use of linalool, citral, eugenol and thymol.

\section{Materials and methods}

The major essential oils (EO) p.a. grade components; linalool $\left(97 \% \mathrm{v} \mathrm{v}^{-1}\right)$, citral $\left(95 \% \mathrm{v} \mathrm{v}^{-1}\right)$, eugenol $\left(99 \% \mathrm{v} \mathrm{v}^{-1}\right)$ and thymol $\left(99 \% \mathrm{v} \mathrm{v}^{-1}\right)$, were purchased from the SigmaAldrich company.

\section{Microorganism, storage and inoculum standardization}

The strain used was S. flexneri INCQS 00152 (ATCC 12022) supplied by the Collection of Reference Microorganisms in Sanitary Surveillance of the Oswaldo Cruz Foundation (FIOCRUZ/CMRVS-WDCM 575). Stock cultures were stored in freezing medium $(15 \mathrm{~mL}$ glycerol, $0.5 \mathrm{~g}$ bacterial peptone, $0.3 \mathrm{~g}$ yeast extract, $0.5 \mathrm{~g}$ sodium chloride, $100 \mathrm{~mL}$ distilled water, and $\mathrm{pH}$ adjusted to 7.0). Cultures were reactivated by inoculating $100 \mu \mathrm{L}$ aliquots into tubes containing $10 \mathrm{~mL}$ brain-heart infusion (BHI) broth and incubated at $37^{\circ} \mathrm{C}$ for $24 \mathrm{~h}$. The inoculum standardization performed by using a growth curve with absorbance monitoring $\left(\mathrm{OD}_{600 \mathrm{~nm}}\right)$ of the tryptone soy broth (TSB) culture in a spectrophotometer (BEL SP-200) and plating in tryptic soy agar (TSA). The plates were incubated at $37^{\circ} \mathrm{C}$ for $24 \mathrm{~h}$ and cultures were stand-

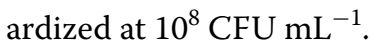

\section{Planktonic cell death curve of $S$. flexneri exposed to major components}

Exposure time influence of $S$. flexneri at different concentrations of linalool, citral, eugenol and thymol was determined through the absorbance $\left(\mathrm{OD}_{600 \mathrm{~nm}}\right)$ monitoring in a spectrophotometer (uv BEL SP-200) every $1.0 \mathrm{~h}$. Aliquots of $1 \mathrm{~mL}$ of standard cultures were inoculated into a flask containing $100 \mathrm{~mL}$ TSB plus $0.5 \%$ Tween 80 and different concentrations of major components [0.0, 0.0625, 0.125 and $\left.0.5 \%\left(\mathrm{v} \mathrm{v}^{-1}\right)\right]$. Cultures were incubated at $37{ }^{\circ} \mathrm{C}$ for $8 \mathrm{~h}$. The experiment was performed in triplicate with three repetitions.

\section{Selection of the main major components against planktonic cells of $S$. flexneri}

The selection of the major components with greater antimicrobial effectiveness against planktonic cells (PC) of S. flexneri was performed using the Plackett \& Burman design (Rodrigues and Lemma 2012), with eight treatments (PB 8) and 3 central points, according to Table 1.

The solutions were prepared in TSB added with $0.5 \%$ Tween 80 and different concentrations of linalool, citral, eugenol and thymol (Table 1). Aliquots of $10 \mu \mathrm{L}$ of standardized culture were transferred into $150 \mu \mathrm{L}$ of solutions contained in the polystyrene microplates and incubated at $37^{\circ} \mathrm{C}$ for $24 \mathrm{~h}$. Subsequently, aliquots of each culture were plated in TSA then incubated at $37^{\circ} \mathrm{C}$ for $24 \mathrm{~h}$.

\section{Determination of the minimum bactericidal concentration (MBC) of mixtures of the major components on planktonic cells}

The MBC of the mixtures of linalool, thymol and citral were determined using the central composite rotational design (CCRD) of $2^{3}$ with four center points and six 
Table 1 Plackett \& Burman 8 matrix containing coded and real values

\begin{tabular}{|c|c|c|c|c|c|c|c|c|}
\hline \multirow[t]{2}{*}{ Test } & \multicolumn{4}{|c|}{ Coded values } & \multicolumn{4}{|c|}{ Real values $\left(\mathrm{v} \mathrm{v}^{-1}\right)$} \\
\hline & $x_{1}$ & $x_{2}$ & $x_{3}$ & $x_{4}$ & Linalool & Citral & Eugenol & Thymol \\
\hline 1 & +1 & -1 & -1 & +1 & 0.0156 & 0 & 0 & 0.0625 \\
\hline 2 & +1 & +1 & -1 & -1 & 0.0156 & 0.0625 & 0 & 0 \\
\hline 3 & +1 & +1 & +1 & -1 & 0.0156 & 0.0625 & 0.0313 & 0 \\
\hline 4 & -1 & +1 & +1 & +1 & 0 & 0.0625 & 0.0313 & 0.0625 \\
\hline 5 & +1 & -1 & +1 & +1 & 0.0156 & 0 & 0.0313 & 0.0625 \\
\hline 6 & -1 & +1 & -1 & +1 & 0 & 0.0625 & 0 & 0.0625 \\
\hline 7 & -1 & -1 & +1 & -1 & 0 & 0 & 0.0313 & 0 \\
\hline 8 & -1 & -1 & -1 & -1 & 0 & 0 & 0 & 0 \\
\hline 9 & 0 & 0 & 0 & 0 & 0.0078 & 0.0313 & 0.01563 & 0.0313 \\
\hline 10 & 0 & 0 & 0 & 0 & 0.0078 & 0.0313 & 0.01563 & 0.0313 \\
\hline 11 & 0 & 0 & 0 & 0 & 0.0078 & 0.0313 & 0.01563 & 0.0313 \\
\hline
\end{tabular}

$\mathrm{x}_{1}, \mathrm{x}_{2}, \mathrm{x}_{3}$ e $\mathrm{x}_{4}$-codified values of linalool, citral, eugenol and thymol respectively

axial points, totaling 18 assays. The independent variables were concentration of linalool, citral and thymol. The relationship between the coded and real values of the independent variables are presented in Table 2. The response variable was $\mathrm{CFU} \mathrm{mL}^{-1}$.

The experiment was carried out by using 96-well polystyrene microplates. The solutions were prepared in TSB added with $0.5 \%$ Tween 80 and different mixtures of major constituent mixtures (Table 2). Aliquots of $10 \mu \mathrm{L}$ of standard culture were inoculated into the microwells containing the solutions and incubated at $37^{\circ} \mathrm{C}$ for $24 \mathrm{~h}$. After incubation, aliquots of the cultures were plated in TSA and incubated at $37^{\circ} \mathrm{C}$ for $24 \mathrm{~h}$.

\section{Formation of S. flexneri biofilm in microplates}

The methodology of Vukovic et al. (2000) was used to evaluate biofilm formation capacity and the optical density of the biofilm (OD) and the optical density of the negative growth control (ODc) in microplates were measured. Aliquots $(50 \mu \mathrm{L})$ of the cultures were inoculated into 96-well polystyrene microplates containing $150 \mu \mathrm{L}$ the tryptone soy broth (TSB) and incubated at $37{ }^{\circ} \mathrm{C}$ for $48 \mathrm{~h}$. The final values of optical density were obtained by the arithmetic means of the absorbances read at OD
$600 \mathrm{~nm}$ in a spectrophotometer (TECAN Infinity ${ }^{\circledR}$ M200 PRO) operated by the I-control ${ }^{\circledR}$ software version 3.37 . The essays were performed in triplicate with eight repetitions. In order to determine the biofilm formation capacity the following classification was used: $\mathrm{OD} \leq \mathrm{ODc}=$ no biofilm producer; $\mathrm{ODc}<\mathrm{OD} \leq 2 \times \mathrm{ODc}=$ weak biofilm producer; $2 \times \mathrm{ODc}<\mathrm{OD} \leq 4 \times \mathrm{ODc}=$ moderate biofilm producer; $\mathrm{OD}>4 \times \mathrm{ODc}=$ strong biofilm producer.

\section{Biofilm minimum bactericidal concentration (BMBC) of major components}

Linalool, citral, eugenol and thymol were added to the microplates containing S. flexneri biofilms at different concentrations. Solutions were prepared in sterile distilled water containing $0.5 \%$ Tween 80 and put in vortex for $2 \mathrm{~min}$. Aliquots containing $200 \mu \mathrm{L}$ solutions at concentrations of $0.50,1.00,1.50,2.00,2.50,3.00$, and $3.50 \%$ $\left(\mathrm{v} \mathrm{v}^{-1}\right)$ were added to the culture wells. After 20 min of contact, the solutions were removed and the wells were washed three times with saline solution $(0.85 \% \mathrm{w} / \mathrm{v})$. Then, $200 \mu \mathrm{L}$ of TSB were added to the wells and the microplates were incubated at $37^{\circ} \mathrm{C}$ for $24 \mathrm{~h}$. After incubation, $10 \mu \mathrm{L}$ of culture was plating in TSA with incubation at $37{ }^{\circ} \mathrm{C}$ for $24 \mathrm{~h}$. The BMBC of major components

Table 2 CCRD matrix with coded and real values of the major components for evaluation of the S. flexneri growth as planktonic cells (PC)

\begin{tabular}{|c|c|c|c|c|c|c|}
\hline \multirow[t]{2}{*}{ Variables } & \multirow[t]{2}{*}{ Code } & \multicolumn{5}{|c|}{ Concentration $\left(\% \mathrm{v} \mathrm{v}^{-1}\right)$} \\
\hline & & -1.68 & -1 & 0 & 1 & +1.68 \\
\hline Linalool & $x_{1}$ & 0.0003 & 0.0027 & 0.0063 & 0.0099 & 0.0124 \\
\hline Citral & $x_{2}$ & 0.0001 & 0.0113 & 0.0278 & 0.0443 & 0.0555 \\
\hline Thymol & $x_{3}$ & 0.0001 & 0.0113 & 0.0278 & 0.0443 & 0.0555 \\
\hline
\end{tabular}


were considered those in which there was no TSA growth after incubation. The experiment was performed in triplicate.

\section{Assessment of the minimum bactericidal concentration of major component combinations on S. flexneri biofilm (BMBC)}

The CCRD of $2^{3}$ was carried out with six axial points and four center points, totaling 18 experiments, being evaluated three independent variables: concentration of linalool, citral and thymol (Table 3). The response variable was $\log$ CFU mL $\mathrm{mL}^{-1}$.

The solutions of the major components were prepared in sterile distilled water of $0.5 \%$ Tween 80 and put in vortex for $2 \mathrm{~min}$. Aliquots of $200 \mu \mathrm{L}$ of the component mixture solutions were added into the wells. After $20 \mathrm{~min}$ of contact, the solutions were removed, the wells were washed three times with saline solution $(0.85 \% \mathrm{w} / \mathrm{v})$ and added with $200 \mu \mathrm{L}$ of TSB. Microtiter plates were incubated at $37^{\circ} \mathrm{C}$ for $24 \mathrm{~h}$, then plated in TSA and incubated again at $37^{\circ} \mathrm{C}$ for $24 \mathrm{~h}$. Combinations of major components where there was not growth in plates were considered as BMBC.

\section{Evaluation of the antimicrobial activity of the major} components on S. flexneri biofilm formed on stainless steel coupons

Shigella flexneri biofilms were formed on coupons of stainless steel AISI $304(1 \times 8 \times 18 \mathrm{~mm}) \# 4$, previously sanitized and sterilized. The coupons were immersed into Petri dishes $(20 \times 100 \mathrm{~mm})$ containing $40 \mathrm{~mL}$ TSB in and inoculated with $1 \mathrm{~mL}$ of the standardized culture of S. flexneri. Incubation with stirring of $25 \mathrm{rpm}$ was performed at $37{ }^{\circ} \mathrm{C}$ for $48 \mathrm{~h}$. After incubation, the coupons were removed, washed three times with saline solution to remove the unattached cells and immersed into solutions of major constituent mixtures for $20 \mathrm{~min}$. Solutions were prepared in sterile distilled water added with $0.5 \%$ Tween 80 and major components at the concentrations generated according to the CCRD matrix of Table 3 . The second washing, was then performed to remove the major components followed by the addition of TSB and incubation for $24 \mathrm{~h}$. After incubation, the biofilm-borne cells were taken through swab smear. Next, the swabs were transferred to saline solution, stirred and then aliquots of the bacterial suspensions were plated on TSA and incubated at $37{ }^{\circ} \mathrm{C}$ for $24 \mathrm{~h}$. The result was presented in CFU by $144 \mathrm{~mm}^{2}$.

The antimicrobial action of the different solutions containing the major components linalool, citral and thymol was compared with $3 \% \mathrm{v} / \mathrm{v}$ quaternary ammonium (Sandet) action, a widely used commercial chemical disinfectant in the food industry.

\section{Statistical analysis}

The Statistica 8.0 software (Statsoft Inc, 2008) was used for the statistical analysis of all experimental results in this paper, with $5 \%$ significance for CCRD and for the essays of the reduction of $S$. flexneri populations in the coupons and with $10 \%$ significance for PB design.

\section{Results}

The antimicrobial activity of essential oil major components was evaluated against $S$. flexneri through absorbance as a function of time in hours. Figure 1 shows the growth/death curves of $S$. flexneri in medium at

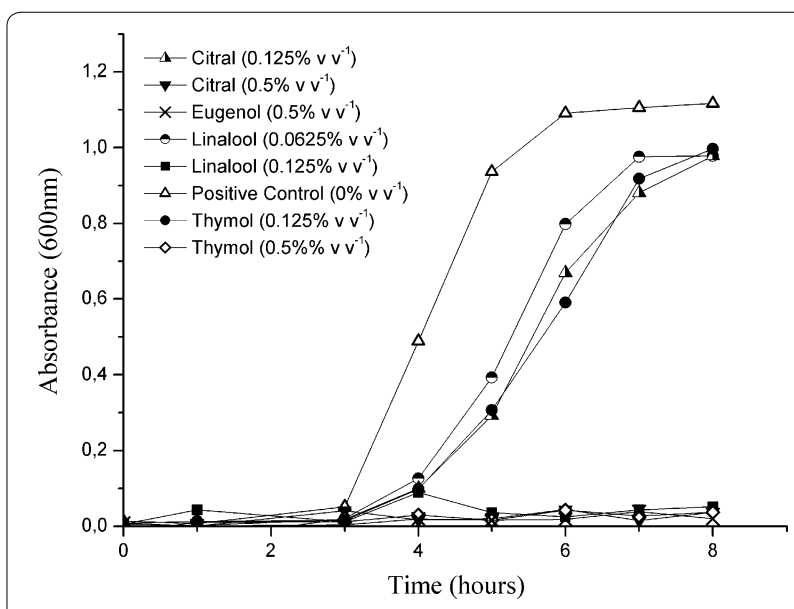

Fig. 1 Planktonic cell growth curve of S. flexneri in medium with EO major components

Table 3 CCRD matrix with coded and real values of the major components for determination of the minimum bactericidal concentration for $S$. flexneri biofilm growth

\begin{tabular}{|c|c|c|c|c|c|c|}
\hline \multirow[t]{2}{*}{ Variables } & \multirow[t]{2}{*}{ Code } & \multicolumn{5}{|c|}{ Concentration $\left(\% \mathrm{v} \mathrm{v}^{-1}\right)$} \\
\hline & & -1.68 & -1 & 0 & 1 & +1.68 \\
\hline Linalool & $x_{1}$ & 0.0001 & 0.0142 & 0.0350 & 0.0558 & 0.0699 \\
\hline Citral & $x_{2}$ & 0.0001 & 0.0142 & 0.0350 & 0.0558 & 0.0699 \\
\hline Thymol & $x_{3}$ & 0.0001 & 0.0810 & 0.2000 & 0.3190 & 0.3999 \\
\hline
\end{tabular}


different concentrations of linalool, citral, eugenol and thymol, incubated for $8 \mathrm{~h}$ at $37^{\circ} \mathrm{C}$.

All analyzed compounds showed bactericidal activity on S. flexneri. Linalool was the component with the highest bactericidal activity, inhibiting the growth of $S$. flexneri at the concentration of $0.125 \%\left(\mathrm{v} \mathrm{v}^{-1}\right)$. For the other components, the bactericidal activity was observed at the concentration of $0.5 \%\left(\mathrm{v} \mathrm{v}^{-1}\right)$. All components did not inhibit S. flexneri at concentrations below $0.0625 \%\left(\mathrm{v} \mathrm{v}^{-1}\right)$.

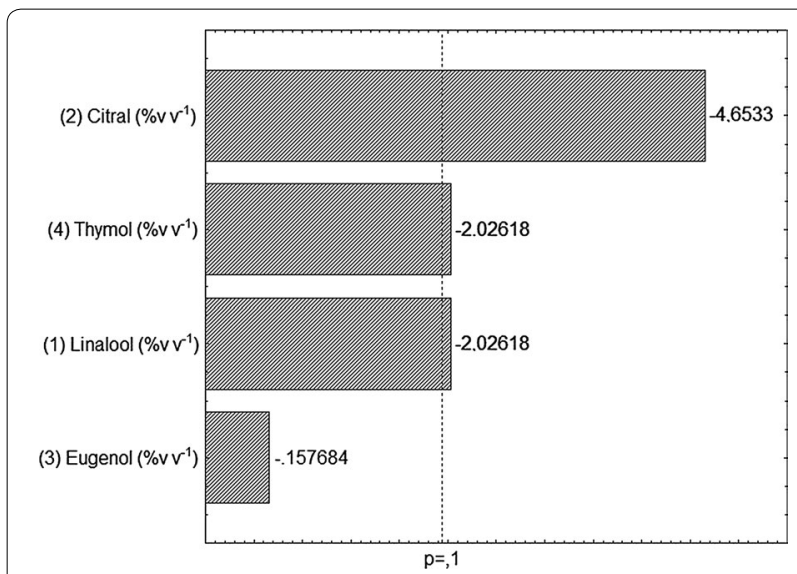

Fig. 2 Pareto chart with estimated effect (absolute value) of the studied variables in the PB 8 experimental design for growth control of S. flexneri
The antimicrobial synergism among the major components on PC was initially studied using the Plackett \& Burman design 8 (PB 8). There was only cell growth of Shigella in treatments 1, 5, 7 and 8. Pareto chart of the studied variables in the PB design for the growth of $S$. flexneri is shown in Fig. 2.

In the selection of variables, the components citral, linalool and thymol had significant negative effects, with $90 \%$ confidence level, showing that they were efficient in inhibiting PCs of S. flexneri. It is observed that when the concentrations of these variables increase from level -1 to +1 , the antimicrobial activity of these components is increased. Thus, citral, linalool and thymol were selected for further experiments.

Central composite rotational designs was used to determine the best concentrations of the EOs major components for growth inhibition of S. flexneri. Table 5 shows the experimental data regarding $S$. flexneri cell growth in the planktonic form at different concentrations of linalool, citral and thymol.

It is observed in Table 4 that in assays 4 (0.0099 linalool, 0.0443 citral, $0.0113 \% \mathrm{v} \mathrm{v}^{-1}$ thymol), $7(0.0027$ linalool, 0.0443 citral, $0.0443 \% \mathrm{v} \mathrm{v}^{-1}$ thymol), 8 (0.0099 linalool, 0.0443 citral, $0.0443 \% \mathrm{v} \mathrm{v}^{-1}$ thymol), $12(0.0063$ linalool, 0.0555 citral, $0.0278 \% \mathrm{v} \mathrm{v}^{-1}$ thymol) and 14 (0.0063 linalool, 0.0278 citral, $0.0555 \% \mathrm{v} \mathrm{v}^{-1}$ thymol), there was no growth of planktonic cells incubated for $24 \mathrm{~h}$ at $37^{\circ} \mathrm{C}$. For the other assays, there was growth.

Table 4 CCRD results for planktonic cells (PC) count of Shigella flexneri (Log CFU mL ${ }^{-1}$ )

\begin{tabular}{|c|c|c|c|c|c|c|c|}
\hline \multirow[t]{2}{*}{ Test } & \multicolumn{3}{|c|}{ Codified values } & \multicolumn{3}{|c|}{ Real values $\left(\% v^{-1}\right)$} & \multirow{2}{*}{$\begin{array}{l}\text { Log } \mathrm{CFU} \mathrm{mL}^{-1} \\
\text { Planktonics cells }\end{array}$} \\
\hline & $\mathrm{X} 1$ & $\mathrm{X} 2$ & $\mathrm{X} 3$ & Linalool & Citral & Thymol & \\
\hline 1 & -1 & -1 & -1 & 0.0027 & 0.0113 & 0.0113 & 7.3711 \\
\hline 2 & 1 & -1 & -1 & 0.0099 & 0.0113 & 0.0113 & 7.8451 \\
\hline 3 & -1 & 1 & -1 & 0.0027 & 0.0443 & 0.0113 & 5.8325 \\
\hline 4 & 1 & 1 & -1 & 0.0099 & 0.0443 & 0.0113 & 0.0 \\
\hline 5 & -1 & -1 & 1 & 0.0027 & 0.0113 & 0.0443 & 5.6628 \\
\hline 6 & 1 & -1 & 1 & 0.0099 & 0.0113 & 0.0443 & 6.3345 \\
\hline 7 & -1 & 1 & 1 & 0.0027 & 0.0443 & 0.0443 & 0.0 \\
\hline 8 & 1 & 1 & 1 & 0.0099 & 0.0443 & 0.0443 & 0.0 \\
\hline 9 & -1.68 & 0 & 0 & 0.0003 & 0.0278 & 0.0278 & 6.5038 \\
\hline 10 & 1.68 & 0 & 0 & 0.0124 & 0.0278 & 0.0278 & 6.6776 \\
\hline 11 & 0 & -1.68 & 0 & 0.0063 & 0.0001 & 0.0278 & 8.2945 \\
\hline 12 & 0 & 1.68 & 0 & 0.0063 & 0.0555 & 0.0278 & 0.0 \\
\hline 13 & 0 & 0 & -1.68 & 0.0063 & 0.0278 & 0.0001 & 8.2945 \\
\hline 14 & 0 & 0 & 1.68 & 0.0063 & 0.0278 & 0.0555 & 0.0 \\
\hline 15 & 0 & 0 & 0 & 0.0063 & 0.0278 & 0.0278 & 7.5185 \\
\hline 16 & 0 & 0 & 0 & 0.0063 & 0.0278 & 0.0278 & 7.7243 \\
\hline 17 & 0 & 0 & 0 & 0.0063 & 0.0278 & 0.0278 & 7.7634 \\
\hline 18 & 0 & 0 & 0 & 0.0063 & 0.0278 & 0.0278 & 7.7482 \\
\hline
\end{tabular}

$\mathrm{X} 1, \mathrm{X} 2, \mathrm{X} 3$ - coded and real values of linalool, citral and thymol concentrations respectively 
Table 5 Regression coefficients of planktonic cells (PC) count of S. flexneri (Log CFU mL ${ }^{-1}$ )

\begin{tabular}{|c|c|c|c|c|c|c|c|c|c|c|}
\hline Source of variation & $\begin{array}{l}\text { Average/ } \\
\text { interaction }\end{array}$ & $\mathrm{X}_{1}(\mathrm{~L})$ & $X_{1}(Q)$ & $\mathrm{X}_{2}(\mathrm{~L})$ & $X_{2}(Q)$ & $X_{3}(L)$ & $X_{3}(Q)$ & $x_{1} x_{2}$ & $x_{1} x_{3}$ & $x_{2} x_{3}$ \\
\hline \multicolumn{11}{|c|}{ Planktonic Cells Count (PC) (Log CFU mL $\mathrm{mL}^{-1}$ ) } \\
\hline Regression & 7.722 & -0.322 & -0.533 & -2.588 & -1.398 & -1.685 & -1.398 & -0.872 & 0.754 & -0.327 \\
\hline$p$ value & 0.000 & 0.374 & 0.173 & 0.000 & 0.004 & 0.001 & 0.004 & 0.087 & 0.130 & 0.486 \\
\hline$R^{2}$ & 0.935 & & & & & & & & & \\
\hline
\end{tabular}

Significant values $(p<0.05)$ are highlighted in italics

$X_{1}$ linalool, $X_{2}$ citral, $X_{3}$ thymol, $L$ linear, $Q$ quadratic

When comparing the antimicrobial activity of assays $4,7,8,12$ and 14 with those of the same components, nevertheless, pure, on the $\mathrm{PC}$, it is noted that the antimicrobial action occurs at concentrations about 10-50 times more diluted, since the MIC for linalool, citral and thymol were $0.125 ; 0.5$ and $0.5 \%\left(\mathrm{v} \mathrm{v}^{-1}\right)$, respectively.

Multiple regression analyses were carried out for the variable CFU $\mathrm{mL}^{-1}$ of planktonic cells based on the experimental data presented on Table 4. Table 5 presents the regression coefficients for growth of $S$. flexneri, where the significant values $(\mathrm{p}<0.05)$ are highlighted. It can be seen that the linear and quadratic terms of citral and thymol concentrations presented significant negative effects on the PC counting at 95\% confidence level.

This means that an increase in the citral and thymol concentration reduced PC counts. Disregarding the non-significant terms, the reparameterized models were obtained for planktonic cell counts of $S$. flexneri INCQS 00152, Eq. 1.

$$
\begin{aligned}
& \log \text { CFU mL }{ }^{-1}=7.1498-2.5882 x_{2}-1.6846 x_{3} \\
& -1.2872 x_{2}^{2}-1.2872 x_{3}^{2}
\end{aligned}
$$

The ANOVA of the quadratic regression reparameterized model for the PC counts was significant $(\mathrm{p}<0.05)$, since the $F_{\text {calc }}$ regression value (18.59) was higher than the value of Ftab $\left(\mathrm{F}_{4 ; 13 ; 0.05}=3.18\right)$. The determination coefficient $\left(\mathrm{R}^{2}\right)$ was high $(0.851)$. This indicated that the reparameterized model for PC counts had a good fit and could be applied for response prediction. Contour curve that describe the influence of thymol and citral on the counting of planktonic cells is shown in Fig. 3.

It is observed that when higher concentrations of citral and thymol are added to the medium (above $0.0443 \%$ $\mathrm{v} \mathrm{v}^{-1}$ ), the lowest PC counts of S. flexneri are obtained. The antibacterial action of citral was higher, as can be observed by the higher coefficient of the linear term for citral in the Eq. $1(-2.5882)$ when compared to the coefficient of the linear term for thymol $(-1.6846)$.

Thus, for the highest possible antibacterial action on PCs of S. flexneri, it is suggested the addition of citral and thymol at concentrations above $0.0443 \% \mathrm{v} \mathrm{v}^{-1}$.

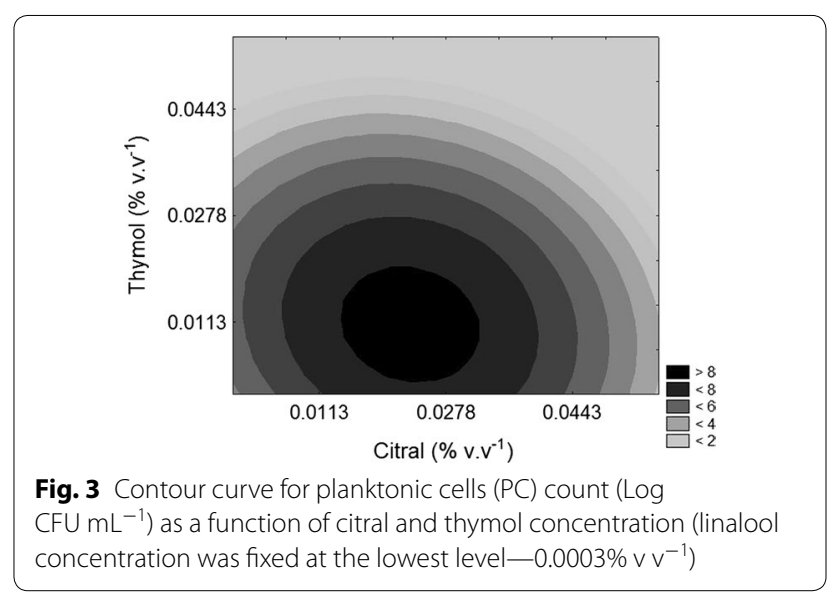

The results of the optical density of the negative growth control (ODc) and optical density of the biofilm (OD) were 0.05 and 1.05 respectively. These results of the formation of $S$. flexneri biofilm in microplates showed that this microorganism is a strong biofilm producer. Thus, experiments with $S$. flexneri biofilms were performed.

When in biofilm, S. flexneri was more resistant to antimicrobials, being that BMBC was 2-24 times higher in the analyzed components than those determined for PC of S. flexneri. The most effective component against the bacterium was citral, which $\mathrm{BMBC}$ was $1 \%$. Eugenol and thymol showed the same BMBC (2\%). Although linalool was the most effective one against $\mathrm{PC}$, it did not show the same effect on the biofilm, being BMBC of $3 \% \mathrm{v} \mathrm{v}^{-1}$. Table 6 shows biofilm of S. flexneri cellular growth experimental data treated with different linalool, citral and thymol concentrations.

In regard to biofilms, it can be observed in Table 6 that, only assays 8 (0.0558 linalool, 0.0558 citral, $0.319 \% \mathrm{v} \mathrm{v}^{-1}$ thymol) and 14 (0.035 linalool, 0.035 citral and 0.3999\% $\mathrm{v} \mathrm{v}^{-1}$ thymol) did not show growth after 20 min of exposure. These results indicate that the presence of components as linalool, citral and thymol affect the growth of biofilm cells. When comparing the antimicrobial activity of assays 8 and 14 with the components used in isolation in the $\mathrm{BC}$, the antimicrobial action was observed with concentrations from 6 to 86 times more diluted, since 
Table 6 Results for biofilm cells count of Shigella flexneri (Log CFU mL ${ }^{-1}$ )

\begin{tabular}{|c|c|c|c|c|c|c|c|}
\hline \multirow[t]{2}{*}{ Test } & \multicolumn{3}{|c|}{ Codified values } & \multicolumn{3}{|c|}{ Real values $\left(\% \mathrm{v} \mathrm{v}^{-1}\right)$} & \multirow{2}{*}{$\begin{array}{l}\text { Log CFU } \mathrm{mL}^{-1} \\
\text { Biofilm }\end{array}$} \\
\hline & $\mathrm{X} 1$ & $\mathrm{X} 2$ & $\mathrm{X} 3$ & Linalool & Citral & Thymol & \\
\hline 1 & -1 & -1 & -1 & 0.0142 & 0.0142 & 0.081 & 6.382 \\
\hline 2 & 1 & -1 & -1 & 0.0558 & 0.0142 & 0.081 & 6.3139 \\
\hline 3 & -1 & 1 & -1 & 0.0142 & 0.0558 & 0.081 & 6.3692 \\
\hline 4 & 1 & 1 & -1 & 0.0558 & 0.0558 & 0.081 & 6.0645 \\
\hline 5 & -1 & -1 & 1 & 0.0142 & 0.0142 & 0.319 & 6.0934 \\
\hline 6 & 1 & -1 & 1 & 0.0558 & 0.0142 & 0.319 & 6.0492 \\
\hline 7 & -1 & 1 & 1 & 0.0142 & 0.0558 & 0.319 & 6.0934 \\
\hline 8 & 1 & 1 & 1 & 0.0558 & 0.0558 & 0.319 & 0 \\
\hline 9 & -1.68 & 0 & 0 & 0.0001 & 0.035 & 0.2 & 7.0969 \\
\hline 10 & 1.68 & 0 & 0 & 0.0699 & 0.035 & 0.2 & 5.8513 \\
\hline 11 & 0 & -1.68 & 0 & 0.035 & 0.0001 & 0.2 & 6.3874 \\
\hline 12 & 0 & 1.68 & 0 & 0.035 & 0.0699 & 0.2 & 6.2765 \\
\hline 13 & 0 & 0 & -1.68 & 0.035 & 0.035 & 0.0001 & 7.9731 \\
\hline 14 & 0 & 0 & 1.68 & 0.035 & 0.035 & 0.3999 & 0 \\
\hline 15 & 0 & 0 & 0 & 0.035 & 0.035 & 0.2 & 7.7782 \\
\hline 16 & 0 & 0 & 0 & 0.035 & 0.035 & 0.2 & 7.6021 \\
\hline 17 & 0 & 0 & 0 & 0.035 & 0.035 & 0.2 & 7.6532 \\
\hline 18 & 0 & 0 & 0 & 0.035 & 0.035 & 0.2 & 7.7634 \\
\hline
\end{tabular}

$\mathrm{X} 1, \mathrm{X} 2, \mathrm{X} 3$ - coded and real values of linalool, citral and thymol concentrations, respectively

the BMBC for linalool, citral and thymol were 3,1 and $2 \%\left(\mathrm{v} \mathrm{v}^{-1}\right)$, respectively. Therefore, it was observed that, the use of valid combinations allows rationalizing these natural compounds and obtaining positive results on the growth inhibition of $S$. flexneri.

The multiple regression analysis for the variable CFU mL mL $\mathrm{mL}^{-1}$ for the biofilm cells shows that the thymol concentration linear and quadratic terms of the model below the $\mathrm{BC}$ count showed significant negative effects at 95\% confidence level.

$$
\text { Log CFU mL }{ }^{-1} \text { Biofilm }=6.8679-1.4869 \mathrm{x}_{3}-1.1634 \mathrm{x}_{3}^{2}
$$

This means that the increased concentration of thymol reduces the cell count in biofilm, within the established limits in the present study. The parameters with $(\mathrm{p}<0.05)$ were considered as significant. Table 7 presents the regression coefficients for growth curve of S. flexneri, being highlighted the significant values $(\mathrm{p}<0.05)$.

By disregarding the non-significant terms, the reparameterized model was obtained for cell counts in biofilm of S. flexneri. Although the ANOVA of the quadratic regression model for the $B C$ count was significant $(\mathrm{p}<0.05)$, the coefficient of determination $\left(\mathrm{R}^{2}\right)$ was low $(0.544)$, indicating a low model fitting to the experimental data.

In Table 6 it can be seen that in trials $8(0.0558 \%$ $\mathrm{v} \mathrm{v}^{-1}$ linalool, $0.0558 \% \mathrm{v} \mathrm{v}^{-1}$ citral, $0.319 \% \mathrm{v} \mathrm{v}^{-1}$ thy$\mathrm{mol})$ and $14\left(0.035 \% \mathrm{v} \mathrm{v}^{-1}\right.$ linalool, $0.035 \% \mathrm{v} \mathrm{v}^{-1}$ citral and $0.3999 \% \mathrm{v} \mathrm{v}^{-1}$ thymol) no growth of Shigella was observed in microplate. Experiments were then carried out with the same concentrations, but in stainless steel coupons. Stain steel coupons treated with Shigella were tested with EOs. The results showed growth of Shigella $\left(5.36 \pm 0.03\right.$ and $5.31 \pm 0.08$ in Log CFU mL $\left.{ }^{-1}\right)$, after $20 \mathrm{~min}$ of exposure of the major essential oils

Table 7 Regression coefficients of biofilm cells (BC) count of S. flexneri (Log CFU mL ${ }^{-1}$ )

\begin{tabular}{|c|c|c|c|c|c|c|c|c|c|c|}
\hline Source of variation & $\begin{array}{l}\text { Average/ } \\
\text { interaction }\end{array}$ & $\mathrm{X}_{1}(\mathrm{~L})$ & $X_{1}(Q)$ & $\mathrm{X}_{2}(\mathrm{~L})$ & $\mathrm{X}_{2}(\mathrm{Q})$ & $X_{3}(L)$ & $X_{3}(Q)$ & $x_{1} x_{2}$ & $x_{1} x_{3}$ & $x_{2} x_{3}$ \\
\hline \multicolumn{11}{|c|}{ Biofilm cells count (BC) (Log CFU mL ${ }^{-1}$ ) } \\
\hline Regression & 7.702 & -0.631 & -0.444 & -0.476 & -0.494 & -1.487 & -1.325 & -0.786 & -0.721 & -0.723 \\
\hline p-value & 0.000 & 0.120 & 0.273 & 0.226 & 0.227 & 0.003 & 0.008 & 0.136 & 0.167 & 0.165 \\
\hline$R^{2}$ & 0.839 & & & & & & & & & \\
\hline
\end{tabular}

Significant values $(p<0.05)$ are highlighted in italics

$X_{1}$ linalool, $X_{2}$ citral, $X_{3}$ thymol, $L$ linear, $Q$ quadratic 
compounds. When the concentrations of assays 8 and 14 were doubled, biofilm cells growth in the coupons was not noted, the same result observed in the control containing quaternary ammonium.

Statistical analysis of the growth data of biofilm cells of $S$. flexneri in the coupons showed a significant difference between trials 8 and 14 and the same trials with duplicate concentrations $\left(0.1116 \% \mathrm{v} \mathrm{v}^{-1}\right.$ linalool, $0.1116 \% \mathrm{v} \mathrm{v}^{-1}$ citral, $0.638 \% \mathrm{v} \mathrm{v}^{-1}$ thymol) and $(0.070 \%$ $\mathrm{v} \mathrm{v}^{-1}$ linalool, $0.070 \% \mathrm{v} \mathrm{v}^{-1}$ citral and $0.7998 \% \mathrm{v} \mathrm{v}^{-1}$ thymol) verified by Tukey test at $5 \%$ probability.

\section{Discussion}

There are several studies in the literature on the bactericidal effect of EO and its major components. Bagamboula et al. (2004). It was found that carvacrol showed the highest antibacterial activity against $S$. flexneri, S. sonnei, E. coli followed by thymol, whereas both estragole and linalool showed limited antibacterial activity. These authors achieved an inhibitory effect below the detection limit against Enterobacteriaceae at concentration of $0.5 \%\left(\mathrm{v} \mathrm{v}^{-1}\right)$ of carvacrol and thymol. Thus, Korenblum et al. (2013) proved that citral was responsible for the antimicrobial effect as no inhibition difference was observed between the essential oil and its main component. Gaio et al. (2015) evaluated the antibacterial activity of basil essential oil in vitro and in Italian-type sausage and found minimal inhibitory concentration for the growth of Shigella flesneri of $0.75 \mathrm{mg} \mathrm{mL}^{-1}$. For all tested Gram-positive and -negative bacteria, basil essential oil presented antibacterial activity, with the exception of Pseudomonas aeruginosa, and the minimum inhibitory concentration varied from 0.25 to $1.00 \mathrm{mg} \mathrm{g}^{-1}$.

In the present article, linalool, citral, eugenol and thymol analyzed in isolation, inhibited the growth of $S$. flexneri. Nevertheless, as shown in Fig. 1, linalool presented a higher antimicrobial activity against the PC at a concentration of $0.125 \%\left(\mathrm{v} \mathrm{v}^{-1}\right)$. In the same evaluation, the components citral, eugenol and thymol had the same effect in the same bacteria at $0.5 \%\left(\mathrm{v} \mathrm{v}^{-1}\right)$. Thus, this paper suggests such EO natural compounds may comprise a new generation of intelligent antimicrobial sanitizers that can reduce the incidence of foodborne illness caused by S. flexneri. Therefore, the use of these compounds in the food industry as antimicrobial agents are considered promising preservatives and chemical sanitizers substitutes. Khan et al. (2017) commented that organic compounds extracted from plants are an attractive alternative to replace conventional antimicrobial agents.
There are several mechanisms involved in the antimicrobial activity of the EO major components that can begin by the cell membrane degradation, the permeability increase of the membrane, up to the decrease of cytoplasmic pH. According to Mackey and Paga (2009), the mechanism of microbial inactivation by citral seems to be a complex phenomenon involving the occurrence of different types of lesions. Exposure with citral damages the plasma and outer cell membranes. These authors verified that repair of lesioned $E$. coli cells after exposure to citral required lipid synthesis and energy expenditure. Thus, cell membrane is confirmed as being one of the structures involved in microbial inactivation by citral. It was observed Chauhan and Kang (2014) that thymol acts on the membrane integrity, promoting release of intracellular potassium ions and nucleic acids, thus causing irreversible damage of bacterial membranes. Moon and Rhee (2016) noticed that the addition of $0.5 \mathrm{mM}$ thymol to soy sauce reduced the populations to $<2.0 \log \mathrm{CFU} \mathrm{mL} \mathrm{m}^{-1}$ after $5 \mathrm{~min}$, and to below the detection level in $10 \mathrm{~min}$ at $22{ }^{\circ} \mathrm{C}$ (initial populations of Escherichia coli O157:H7, Salmonella Typhimurium and Listeria monocytogenesa were between 7.1 and $7.3 \log$ CFU mL ${ }^{-1}$ ).

The ability of bacteria causing food poisoning to form biofilm is already well established (Valeriano et al. 2012; Oliveira et al. 2010; Millezi et al. 2013; Zhao et al. 2017). Shigella flexneri strain used in the present study was strong biofilm-forming, being highlighted its importance for the food industry. In a study performed in an ice cream processing facility, both Listeria monocytogenes and S. flexneri were highlighted, forming biofilms in the processing line (Gunduz and Tuncel 2006). Sharma and Anand (2002) showed that bacteria of the genus Shigella were among gram-negative biofilm-forming bacteria in milk pasteurization line. Thus, the discovery of new biofilm control strategies in the food industry based on natural substances with high antimicrobial activity seems to be a step forward in overcoming the issue of biofilm resistance (Simões et al. 2010). The antibacterial activity of EO and its components is not attributed to a single element (Kim and Kang 2017). It was observed that the combinations containing linalool, citral and thymol (tests: 4, 7, 8, 12 and 14 in Table 4) showed higher antimicrobial activity against $\mathrm{PC}$ in relation to antimicrobial activity in isolation. The same was observed for BC in the assays 8 and 14 (Table 6). These results show the synergistic effect among the tested EO major components, playing an important role in the death of $\mathrm{PC}$ and $\mathrm{BC}$. However, an additional study is necessary to evaluate the antibacterial action of the compounds used in this work in the case of multi-species biofilms. 
Henri et al. (2012) reported synergistic effects between eugenol and thymol against $E$. coli, where a combined effect resulted in a greater reduction of the bacterial population than when applied in isolation. The authors suggest that thymol disintegrated the outer membrane, facilitating the entry of eugenol into the cytoplasm, thus denaturing proteins. Khan et al. (2017) noticed that thymol and carvacrol induce autolysis, stress, growth inhibition and reduce the biofilm formation by Streptococcus mutans. Other authors have found that thymol and carvacrol exhibited increased antimicrobial activity against pathogenic bacteria (Clostridium perfringens, Escherichia coli and Salmonella) than against beneficial bacteria.

Tables 5 and 7 present the linear increase in PC death and $\mathrm{BC}$ elimination in as much as concentrations were increased. It is clear considering Tables 4 and 6 that the concentrations of linalool, citral and thymol contributed to the removal of $\mathrm{PC}$ and $\mathrm{BC}$. However, only the concentration of citral and thymol were significant for the removal of PC, as shown in Fig. 3 and Table 5. For BC, the thymol concentration was the variable that most contributed to their removal (Table 7). A previous study by Korenblum et al. (2013) showed that planktonic and sessile growth of Desul fovibrio alaskensis isolated from a soured oil reservoir was inhibited by lemongrass essential oil and its major component citral.

Assays 8 (0.0558 linalool, 0.0558 citral, $0.319 \% \mathrm{v} \mathrm{v}^{-1}$ thymol) and 14 (0.035 linalool, 0.035 citral and $0.3999 \% \mathrm{v}$ $\mathrm{v}^{-1}$ thymol) were effective in $\mathrm{BC}$ control in the microtiter plate (Table 6), however, they did not show the same efficiency in $\mathrm{BC}$ control in the coupons. Nevertheless, double concentrations of the assays 8 and 14 for BC exposure of $S$. flexneri formed in the coupons led to reductions at undetectable levels in the bacterial populations of the biofilm. No differences were also observed among the control results (quaternary ammonium, prepared according to the manufacturer's recommendations for $\mathrm{BC}$ control) and double concentrations of the assays 8 and 14 for BC.

Therefore, the naturally occurring phytochemicals studied in this paper, specially citral and timol isolated or combined could be used for microbiological control in the food industry substituting chemical compounds. The obtained model can describe and predict the PC count of $S$. flexneri in medium with the tested major compounds. The major components applied individually or in combination showed also a bactericidal action on the biofilm cells of S. flexneri. In mixtures they showed synergism, allowing the reduction of the concentration of the major components and chemical sanitizers with lower environmental impact and lower cost.

\section{Abbreviations}

PC: planktonic cells; BC: biofilm cells; CCRD: central composite rotational designs; MIC: minimum inhibitory concentration; BMBC: biofilm minimum bactericidal concentration; BHI: brain-heart infusion; EO: essential oils; TSB: tryptone soy broth; OD: optical density; CFU: colony forming unit; PB: Plackett \& Burman design; $M B C$ : minimum bactericidal concentration; ODc: optical density of the negative growth control.

\section{Authors' contributions}

RHP and JGLFA designed the experiments and analyzed the data. MTN and ACFO performed the research, MTN wrote the paper. OLMB and PSM polished the manuscript. All authors read and approved the final manuscript.

\section{Author details}

${ }^{1}$ Laboratory of Bioprocess Engineering, Department of Food Science, Federal University of Lavras, B.O.: 3037, Lavras, MG, 37.200.000, Brazil. ${ }^{2}$ Laboratory of Food Biochemistry, Department of Food Science, Federal University of Lavras, B.O.: 3037, Lavras, MG, 37.200.000, Brazil. ${ }^{3}$ Laboratory of Food Microbiology, Department of Food Science, Federal University of Lavras, B.O.: 3037, Lavras, MG, 37.200.000, Brazil.

\section{Acknowledgements \\ The authors are grateful to Fapemig for financial support, to the Brazilian agency Coordenação de Aperfeiçoamento de Pessoal de Nível Superior/ CAPES (Process Number 9246142) and to the National Council for Scientific and Technological Development (CNPq) for scholarships, and to Collection of Reference Micro-organisms in Sanitary Surveillance of the Oswaldo Cruz Foundation (FIOCRUZ-Brazil) for microorganisms donations.}

\section{Competing interests}

The authors declare that they have no competing interests.

\section{Availability of data and materials}

All data analyzed in this article are included in the figures and tables. Any material used in this article is available for search purposes upon request.

Consent for publication

Not applicable.

\section{Ethics approval and consent to participate}

This article does not contain any studies with human participants or animals performed by any of the authors.

\section{Funding}

This research was supported by the Foundation for Support of Research in the State of Minas Gerais/Brazil (FAPEMIG), project CAG-APQ-00924-13.

\section{Publisher's Note}

Springer Nature remains neutral with regard to jurisdictional claims in published maps and institutional affiliations.

Received: 5 June 2018 Accepted: 14 June 2018

Published online: 25 June 2018

\footnotetext{
References

Ait-Ouazzou A, Cherrat L, Espina L, Lorán S, Rota C, Pagán R (2011) The antimicrobial activity of hydrophobic essential oil constituents acting alone or in combined processes of food preservation. Innov Food Sci Emerg Technol. 12:320-329. https://doi.org/10.1016/j.ifset.2011.04.004

Araújo FM, Dantas MCSM, Silva LS, Aona LYS, Tavares IF (2017) Antibacterial activity and chemical composition of the essential oil of Croton heliotropiifolius Kunth frahia, Amargosa, Bahia, Brazil. Ind Crop Prod 105:203206. https://doi.org/10.1016/j.indcrop.2017.05.016

Arena ET, Campbell-Valois FX, Tinevez JY, Nigro G, Sachse M, Moya-Nilges M, Nothelfer K, Marteyn B, Shorte SL, Sansonetti PJ (2015) Bioimage analysis of Shigella infection reveals targeting of colonic crypts. Proc Natl Acad Sci USA 112:3282-3290. https://doi.org/10.1073/pnas.1509091112
} 
Bagamboula CF, Uyttendaele M, Debevere J (2004) Inhibitory effect of thyme and basil essential oils, carvacrol, thymol, estragol, linalool and p-cymene towards Shigella sonnei and S. flexneri. Food Microbiol 21:33-42. https:// doi.org/10.1016/S0740-0020(03)00046-7

Bassolé IHN, Juliani HR (2012) Essential oils in combination and their antimicrobial properties. Z Phys D At mol Clust 17:3989-4006. https://doi. org/10.3390/molecules 17043989

Beyki M, Zhaveh S, Khalili ST, Rahmani-Cherati T, Abollahi A, Bayat M, Tabatabaei M, Mohsenifar A (2014) Encapsulation of Mentha piperita essential oils in chitosan-cinnamic acid nanogel with enhanced antimicrobial activity against Aspergillus flavus. Ind Crops Prod 54:310-319. https://doi. org/10.1016/j.indcrop.2014.01.033

CENTERS FOR DISEASE CONTROL AND PREVENTION. Shigella-Shigellosis. 2013. Accessed 15 Sept 2017

Chai C, Lee S, Kim J, Oh S (2016) Synergistic antimicrobial effects of organic acids in combination with carvacrol against Shigella sonnei. J Food Saf 36:360-366. https://doi.org/10.1111/jfs.12251

Chauhan AK, Kang SC (2014) Thymol disrupts the membrane integrity of Salmonella ser. typhimurium in vitro and recovers infected macrophages from oxidative stress in an ex vivo model. Res Microbiol 165:559-565. https://doi.org/10.1016/j.resmic.2014.07.001

Costa EM, Silva S, Veiga M, Tavaria FK, Pintado MM (2017) A review of chitosan's effect on oral biofilms: perspectives from the tube to the mouth. J Oral Bioscienc 59:205-210. https://doi.org/10.1016/j.job.2017.07.001

Cruz CBND, Souza MCSD, Serra PT, Santos I, Balieiro A, Pieri FA, Orlandi PP (2014) Virulence factors associated with pediatric Shigellosis in Brazilian Amazon. Biomed Res Int 2014:1-9. https://doi.org/10.1155/2014/539697

Gaio I, Saggiorato AG, Treichel H, Cichoski AJ, Astolfi V, Cardoso RI, Cansian RL (2015) Antibacterial activity of basil essential oil (Ocimum basilicum L.) in Italian-type sausage. J Verbrauch Lebensm 10:323-329. https://doi. org/10.1007/s00003-015-0936-x

Goldbeck JC, Victoria FN, Motta A, Savegnago L, Jacob RG, Perin G, Lenardão EJ, da Silva WP (2014) Bioactivity and morphological changes of bacterial cells after exposure to 3-(p-chlorophenyl) thio citronellal. LWT- Food Sci Tech-Brazil 59:813-819. https://doi.org/10.1016/j.lwt.2014.05.036

Grimont F, Lejay-Collin M, Talukder KA, Carle I, Issenhuth S, Le Roux K, Grimont PA (2007) Identification of a group of Shigella-like isolates as Shigella boydii. J Med Microbiol 20:749-754. https://doi.org/10.1099/jmm.0.46818-0

Gunduz GT, Tuncel G (2006) Biofilm formation in an ice cream plant. Antonie Van Leeuwenhoek 89:329-336. https://doi.org/10.1007/s1048 2-005-9035-9

Henri I, Bassolé N, Juliani HR (2012) Essential oils in combination and their antimicrobial properties. Molecules 17:3989-4006. https://doi.org/10.3390/ molecules 17043989

Hu L, Wai TT (2017) Comparing invasive effects of five foodborne bacterial pathogens in human embryonic intestine 407 cells and human ileocecum HCT-8 cells. Asian Pac J Trop Med. 7:937-944. https://doi. org/10.1016/j.apjtb.2017.09.004

Hyldgaard M, Mygind T, Meyer RL (2012) Essential oils in food preservation: mode of action, synergies and interactions with food matrix components. Front Microbiol 3:1-24. https://doi.org/10.3389/fmicb.2012.00012

Kane KA, Dorman CJ (2012) VirB-mediated positive feedback control of the virulence gene regulatory cascade of Shigella flexneri. J Bacteriol 194:5264-5273. https://doi.org/10.1128/JB.00800-12

Khan ST, Khan M, Ahmad J, Wahab R, Abd-Elkader OH, Musarrat J, Al-Kedhairy AA (2017) Thymol and carvacrol induce autolysis, stress, growth inhibition and reduce the biofilm formation by Streptococcus mutans. AMB Express. 7:49-60. https://doi.org/10.1186/s13568-017-0344-y

Kim S, Kang D (2017) Combination treatment of ohmic heating with various essential oil components for inactivation of food-borne pathogens in buffered peptone water and salsa. Food Control 80:29-36. https://doi. org/10.1016/j.foodcont.2017.04.001
Korenblum E, de Goulart FRV, de Rodrigues IA, Abreu F, Lins U, Alves PB, Seldin $L$ (2013) Antimicrobial action and anti-corrosion effect against sulfate reducing bacteria by lemongrass (Cymbopogon citratus) essential oil and its major component, the citral. AMB Express 3:1-8. https://doi. org/10.1186/2191-0855-3-44

Mackey B, Paga R (2009) Inactivation of Escherichia coli by citral. J Appl Microbiol 108:1928-1939. https://doi.org/10.1111/j.1365-2672.2009.04597x

Mahdavi B, Yaacob WA, Din LB (2017) Chemical composition, antioxidant, and antibacterial activity of essential oils from Etlingera sayapensis AD Poulsen \& Ibrahim. Asian Pac J Trop Med 10:819-826. https://doi. org/10.1016/j.apjtm.2017.08.006

Mani S, Wierzba T, Walker RI (2016) Status of vaccine research and development for Shigella. Vaccine 34:2887-2894. https://doi.org/10.1016/j.vacci ne.2016.02.075

Millezi AF, Cardoso MD, Alves E, Piccoli RH (2013) Reduction of Aeromonas hidrophyla biofilm on stainless stell surface by essential oils. Braz J Microbiol 44:73-80. https://doi.org/10.1590/S1517-83822013005000015

Moon H, Rhee MS (2016) Synergism between carvacrol or thymol increases the antimicrobial efficacy of soy sauce with no sensory impact. Int J Food Microbiol 217:35-41. https://doi.org/10.1016/j.jffoodmicro.2015.10.009

Moradi S, Sadeghi E (2017) Study of the antimicrobial effects of essential oil of Satureja edmondi and nisin on Staphylococcus aureus in commercial soup. J Food Process Preserv 41:1-8. https://doi.org/10.1111/jfpp.13337

Nüesch-Inderbinen M, Heini N, Zurfluh K, Althaus D, Hächler H, Stephan R (2016) Antimicrobial drug resistance mechanisms. Emerg Infect Dis 22:1083-1085. https://doi.org/10.3201/eid2206.152088

Oliveira MMM, Brugnera DF, das Graças Cardoso M, Alves E, Piccoli RH (2010) Disinfectant action of Cymbopogon sp. essential oils in different phases of biofilm formation by Listeria monocytogenes on stainless steel surface. Food Control 21:549-553. https://doi.org/10.1016/j.foodcont.2009.08.003

Rodrigues MI, lemma AF (2012) Experimental design and process optimization. Ed. Casa do EspíritoAmigo Fraternidade Fé e Amor, Campinas, SP, Brazil. Translation: Evan Michael Visser. Revision: Hillary Castle de Menezes, p 352

Sharma M, Anand S (2002) Biofilms evaluation as an essential component of HACCP for food/dairy processing industry - a case. Food Control 13:469-477. https://doi.org/10.1016/S0956-7135(01)00068-8

Simões M, Simões LC, Vieira MJ (2010) A review of current and emergent biofilm control strategies. J Jpn Soc Food Sci Technol 43:573-583. https:// doi.org/10.1016/j.Iwt.2009.12.008

Souza ELD, Meira QGS, Barbosa IDM, Athayde AJAA, Conceição MLD, Siqueira Júnior JPD (2014) Biofilm formation by Staphylococcus aureus from food contact surfaces in a meat-based broth and sensitivity to sanitizers. Braz J Microbiol 45:67-75. https://doi.org/10.1590/S1517-83822014000100010

Srey S, Jahid IK, Ha S (2013) Biofilm formation in food industries: a food safety concern. Food Control 31:572-585. https://doi.org/10.1016/j.foodc ont.2012.12.001

Valeriano C, De Oliveira TLC, De Carvalho SM, das Graças Cardoso M, Alves E, Piccoli RH (2012) The sanitizing action of essential oil-based solutions against Salmonella enterica serotype Enteritidis S64 biofilm formation on AISI 304 stainless steel. Food Control 25:673-677. https://doi. org/10.1016/j.foodcont.2011.12.015

Vukovic D, Dakic I, Savic B, Svabic-vlahovic M (2000) A modified microtiterplate test for quantification of staphylococcal biofilm formation. J microbiol methods 40:175-179. https://doi.org/10.1016/s0167-7012(00)00122 $-6$

Whitehead KA, Verran J (2015) Formation, architecture and functionality of microbial biofilms in the food industry. Curr Opin Food Sci 2:84-91. https ///doi.org/10.1016/j.cofs.2015.02.003

Zhao X, Zhao F, Wang J, Zhong N (2017) Biofilm formation and control strategies of foodborne pathogens: food saf perspect. RSC Adv 7:36670-36683. https://doi.org/10.1039/C7RA02497E 